\title{
A VISITA DE UM AFRO-AMERICANO AO PARÁ́SO RACIAL
}

\author{
Petrônio Domingues \\ Doutor em História-FFLCH/USP \\ Professor da Universidade Federal de Sergipe-UFS
}

\section{Resumo}

Em 1923, o jornalista e empresário afro-americano Robert Abbott visitou o Brasil. De volta aos Estados Unidos, publicou uma série de artigos no jornal Chicago Defender, informando que, aqui, os negros não enfrentavam problemas que dificultasse ou impedisse seu pleno desenvolvimento econômico, social, político, cultural, ou seja, eles viviam numa espécie de paraíso racial. A principal questão que vai ser investigada neste artigo é saber por que Abbott retratou um quadro tão mítico das relações raciais no Brasil.

\section{Palavras-Chave}

Negro $\bullet$ Alteridade $\bullet$ Relações Raciais

\section{Abstract}

In 1923, the journalist and Afro-American entrepreneur Robert Abbott visited Brazil. On return to the United States, he published an article series in the periodical Chicago Defender, informing that, here, negroes did not face problems that raise difficulties or hindered its full economic, social, political or cultural development; in other words, they lived in a kind of racial paradise. The main question that may be investigated in this article is to know why Abbott retracted a picture so mythical of the racial relations in Brazil.

\section{Keywords}

Negro $\bullet$ Diversity $\bullet$ Racial Relationship 
Essa esfinge do nosso futuro o problema ‘do negro’ no Brasil. Nina Rodrigues ${ }^{1}$

Robert S. Abbott (1868-1940) nasceu de pais ex-escravos na Geórgia e estudou no Instituto Hampton (Virgínia), onde aprendeu o ofício de tipógrafo, e na faculdade de Direito em Kent, Chicago. Exerceu a advocacia por um certo tempo em Topeka (Kansas), Gary, Indiana e Chicago, onde fundou o jornal Chicago Defender, em 1905. Em uma década, passou de um jornal de quatro páginas para um dos principais jornais afro-americanos, o que possibilitou condições financeiras para Robert Abbott empreender uma viagem de três meses pela América do Sul, em 1923. Na volta, escreveu uma série de artigos para o Chicago Defender. No primeiro deles, publicado em 4 de agosto daquele ano, Abbott relatava que viajar por aquela região do Novo Mundo foi a realização de um "sonho dourado longamente desejado". As razões da viagem se remetiam, em primeiro lugar, à vontade de observar o progresso social do negro quando "projetado na esfera de uma tradição e de uma cultura latino-européia" e, em segundo lugar, procurar entender de que maneira aquela região poderia servir de celeiro de oportunidades sociais, comerciais e industriais para um grupo de negros norte-americanos "evoluídos", que em breve começaria "a olhar o continente sul americano como o mais provável porto para uma solução de seus problemas individuais". ${ }^{2}$

Porém, logo no início da preparação da viagem, Abbott e sua esposa enfrentaram alguns problemas. O principal deles foi a recusa do cônsul brasileiro em Chicago de conceder vistos de entrada, pelo "simples" fato de os visitantes serem negros. Diante do impasse, ele e sua esposa solicitaram a intervenção do senador Medill McCormik, que negociou junto à embaixada brasileira. Depois de muita pressão, foi liberado o visto de entrada no Brasil. Sem conseguir digerir muito bem o que acontecera, o jornalista afro-americano se indagou: "Isto parece, tem sido a experiência que todo negro norte-americano enfrenta ao tentar entrar no Brasil. Mas por que isto?". Ele preferia acreditar

\footnotetext{
${ }^{1}$ RODRIGUES, Nina. 4. ed. Os africanos no Brasil. São Paulo: Ed. Nacional, 1976, p. 1. 2 “Motivos pessoais". Parte 1. Chicago Defender. Chicago (4 de agosto de 1923). Tradução livre.
} 
que a conduta do cônsul brasileiro em Chicago era "inteiramente contrária à Constituição brasileira e vergonhosamente trata-se de uma variante do temperamento do povo brasileiro".3

Em 11 de agosto, Abbott informava como foi a chegada ao Rio de Janeiro. Após ficar encantado com as belezas naturais da "cidade maravilhosa", descrevia como foi sua primeira experiência de discriminação racial em terra brasilis. Ele e sua esposa foram impedidos de se hospedar no hotel Glória, sob a alegação de que "não havia vagas". Abbott então teria exclamado: "até no reino das fadas, o Brasil, [...] uma coisa nojenta dessas está presente". ${ }^{4}$ Apesar deste incidente inicial, o casal fez rapidamente amizade com pessoas de distinção da cidade. Uma delas foi o Dr. Alfredo Clendenden, um negro norte-americano que veio de Nova York no último quartel do século XIX e era ex-dentista do imperador D. Pedro II. Foi por intermédio dele que Abbott conheceu alguns "homens de cor" de sucesso, como José do Patrocínio Jr, jornalista e filho do famoso abolicionista José do Patrocínio; Juliano Moreira, doutor em medicina e considerado um dos médicos neurologistas mais ilustres do Brasil; Eloy de Souza, senador da República, escritor e jornalista; Sampaio Correia, também senador da República e professor da Escola Superior de Engenharia; Evaristo de Moraes, advogado, tido como um dos maiores criminologistas brasileiros; Dr. Olympio de Castro, um padre de grandes honras acadêmicas. O jornalista afro-americano não ocultou sua admiração em saber que os negros - "negros no sentido literal da palavra", como qualificou - galgavam a posições tão eminentes no Brasil, utilizando-se somente de suas habilidades e competências nos momentos oportunos. A partir daí ele fez, pela primeira vez, a seguinte ilação: "Não há nenhum tipo de problema racial no Brasil". ${ }^{5}$ Afinal, não haveria nenhuma barreira que impediria o livre progresso do negro na sociedade.

Em 18 de agosto, Abbott relatava como foi a chegada dele e da esposa em São Paulo. Procuraram se hospedar no Palace hotel mas, depois de alojados, foram informados que alguns hóspedes não queriam a presença deles ali. Para evitar qualquer tipo de problema, transferiram-se para o Odeste hotel. Esse episódio de racismo, entretanto, não teria comprometido a boa impressão que

\footnotetext{
${ }^{3}$ Idem.

4 “Motivos pessoais". Parte 2. Chicago Defender. Chicago (11 de agosto de 1923).

${ }^{5}$ Idem.
} 
o casal ficou de São Paulo, terra onde o "status social" dos negros seria quase o mesmo de seus irmãos de "cor" do Rio de Janeiro. Abbott observava que, embora o Brasil fosse palco de convivência de quase "todas as raças", havia um estado de "absoluta harmonia social". Ele então traçava um prognóstico otimista: "Um futuro brilhante pode ser assegurado por parte do negro no Brasil, e fora do cruzamento racial no país, virá um povo de instinto progressista, vigoroso, inteligente, belo fisicamente, sem comparação em nenhum outro lugar do planeta". 6

Em $1^{\circ}$ de setembro, o jornalista afro-americano voltava a expressar sua fé de que, no Brasil, não havia nenhum obstáculo que dificultasse ou impedisse o pleno desenvolvimento econômico, social, político e cultural do negro. Ali, escreveu, "o homem ou a mulher que pode fazer alguma coisa, não sofre a menor desvantagem por causa da raça. Os negócios e as profissões são disponíveis a todos, sem preconceito de raça ou cor, e o emprego e a clientela são assegurados por méritos próprios". Também postulava que "a presença do negro se dá em qualquer lugar" no Brasil e que "este goza de facilidades até então inconcebíveis numa democracia atual". ${ }^{7}$ Em virtude desse quadro idílico, ele conclamava os afro-americanos a se estabelecerem e investirem no maior país da América do Sul.

Em 8 de setembro, Abbott comparava o sistema racial brasileiro com o dos Estados Unidos, afirmando que neste país o negro "não tem tido, de forma alguma, uma chance justa para mostrar sua importância junto ao progresso social”, ficando exposto aos "linchamentos, discriminação, privação de direitos de cidadão e mau tratamento de suas mulheres". Nesse contexto, indagava, "como pode um povo progredir quando sofre abusos sociais, não só em relação a um plano de independência financeira, mas em relação ao ápice da coragem, da moralidade e da inteligência como ideais de qualidade no homem"? Já o Brasil era retratado como o país das oportunidades para o negro. Este teria mais importância na vida política e intelectual daqui do que na dos Estados Unidos, onde as oportunidades abertas para o negro seriam comparativamente poucas. No Brasil, indicava o jornalista afro-americano, "é bem diferente"; muitos dos mais altos oficiais do exército e da marinha "são negros. [...] Os negócios, as profissões e o comércio estão abertos

\footnotetext{
6 "São Paulo". Chicago Defender. Chicago (18 de agosto de 1923).

7 “Rio de Janeiro". Parte 2. Chicago Defender. Chicago (1 de setembro de 1923).
} 
para qualquer pessoa. E nosso progresso depende não de tradições no que se refere à raça ou cor, mas à pura habilidade". 8

Em 20 de outubro, Abbott fazia "algumas reflexões" e retomava questões já tratadas anteriormente. Declarava que foi com grande alegria que acompanhou a vida social do negro no Brasil, um país "desembaraçado de qualquer sentimento de racismo". Enfatizava que aqui haveria "perfeita igualdade entre as raças". ${ }^{9}$ Para avalizar seu argumento, relatava o que aconteceu com um grupo de norte-americanos que, durante a Guerra Civil, radicou-se na atual cidade de Americana, em São Paulo:

Certa vez, durante a guerra civil nos Estados Unidos, um número de donos de escravos sulistas, temendo que o resultado da luta seria a vitória do norte, pegou os escravos e outras propriedades e foram para o Brasil, onde a escravidão ainda era possível. Estabelecendo-se no interior, eles imediatamente construíram uma comunidade e nomearam-na de Villa Americana. Lá eles viviam com os escravos produzindo novas plantações durante alguns anos. Isto foi, é claro, uma explosão inesperada para a Villa Americana. Mas hoje, mesmo nesta cidade, a escravidão não deixou nenhuma inconveniência social para o negro. Mais, os filhos e filhas brancos dos antigos donos de escravos casaram e se misturaram livremente com aqueles que eram descendentes de escravos. ${ }^{10}$

No final do artigo, Abbott notificava que estava sendo preparada uma excursão para a "América do Sul" para um grupo de trezentos homens de negócios e profissionais negros, a se realizar no ano de 1925. A excursão teria o propósito duplo de conseguir informações de primeira mão sobre as oportunidades referentes ao investimento comercial e ao mesmo tempo estreitar os laços de união entre o povo sul americano e o negro estadunidense. $\mathrm{O}$ grupo iria visitar a grande cidade negra brasileira, Salvador, na Bahia; navegar pelo rio Amazonas, a fim de conhecer o potencial do vasto território para o cultivo da borracha; visitar Pernambuco, a segunda maior cidade negra do país; passar brevemente pelo Rio de Janeiro

\footnotetext{
8 "Rio de Janeiro". Parte 3. Chicago Defender. Chicago (8 de setembro de 1923).

9 “"Havana e o norte navegante". Chicago Defender. Chicago (20 de outubro de 1923).

${ }^{10}$ Idem.
} 
e terminar a viagem em Buenos Aires, com o intuito de prestar homenagem à memória do General Filucho, o mártir negro da história política da Argentina. De acordo com Abbott, a idéia da viagem era "criar uma conexão no Brasil para o negro norte-americano que deseja estabelecer-se num novo país, sob condições mais harmônicas com a noção de liberdade". ${ }^{11}$

Em 27 de outubro de 1923, Robert Abbott publicava o último artigo no jornal Chicago Defender para descrever como sucedeu sua viagem à "América do Sul". O título do artigo era sugestivo: "Brasil: a terra da oportunidade maravilhosa". Para não deixar pairar nenhuma dúvida de que o sistema racial brasileiro era democrático, assinalava que, aqui, "o fato de o homem ser negro, amarelo ou branco não tem nenhuma importância social. Em verdade, é um país onde o mérito pessoal conta mais do que tudo!...”. E como informação final, dizia para o público leitor de seu jornal: "Não há nenhum país no qual o negro está mais bem situado do que no Brasil". ${ }^{12}$

Como se pode perceber, o fundador do Chicago Defender procurou demonstrar amiúde que o negro brasileiro vivia numa espécie de paraíso racial, desfrutando dos privilégios de um país que pretensamente garantia a plena igualdade de oportunidades para todos os cidadãos, não fazendo nenhum tipo de distinção racial. A principal questão que vai ser investigada nesse artigo é: por que Abbott construiu um quadro quixotesco do padrão das relações raciais no Brasil? Antes de responder essa pergunta, porém, faz-se necessária pautar uma outra questão: qual era a dinâmica do sistema racial brasileiro e estadunidense nas primeiras décadas do século XX?

\section{Estados Unidos: 0 sistema de segregação racial}

Se o Brasil era um suposto paraíso racial para as pessoas de ascendência africana, os Estados Unidos eram o inferno. Em 1863, antes mesmo do fim da Guerra Civil (1861-1865), Abraham Lincoln proclamou a Emancipação, libertando os escravos nos territórios do Sul que haviam se separado da União. Dois anos depois, o Congresso aboliu oficialmente a escravidão em todo o território

\footnotetext{
${ }^{11}$ Idem.

12 "Brasil: a terra da oportunidade maravilhosa". Chicago Defender. Chicago (27 de outubro de 1923).
} 
norte-americano, por meio da $13^{\mathrm{a}}$. Emenda Constitucional. O fim da Guerra Civil foi seguido por uns doze anos de ocupação militar no Sul pelas forças da União, e os negros da região fizeram progressos significativos durante esse período, ganhando, por exemplo, o direito do voto e mobilizando-se politicamente. Depois desse período de "reconstrução", as elites do Sul reconquistaram o poder regional e, com a anuência das elites do Norte, empenharam-se em reverter os ganhos dos negros, usando para isso a violência e o terror. ${ }^{13}$

Entre o último quartel do século XIX e início do século seguinte, foram progressivamente sendo aprovadas leis de segregação racial, separando os brancos e negros nas escolas, nos hotéis e restaurantes, nas lojas, nas composições ferroviárias, nos bondes, nos teatros, cinemas, parques de diversões, cemitérios e lugares de reuniões públicas. Portanto, esse sistema de segregação racial popularmente conhecido como Jim Crow ${ }^{14}$ - não foi construído da noite para o dia; pelo contrário, foi produto de um processo relativamente longo de conflitos sociais e políticos. ${ }^{15}$ É verdade que a segregação prevalecia no Sul dos Estados Unidos, mas também é um fato que muitas leis dessa natureza foram sancionadas no Norte do país.

Arnold Rose assinala que a partir dessa nova conjuntura toda etiqueta, no tocante às relações entre negros e brancos, foi reajustada para "isolar os dois grupos um do outro e para colocar o grupo negro em posição social inferior". ${ }^{16}$ As barbearias e os salões de beleza eram onde existia o mais completo regime separatista. Diversos estabelecimentos particulares (como lojas, mercados e bares) recusavam a atender ou servir afro-americanos e, muitas vezes, coloca-

\footnotetext{
${ }^{13}$ Para o período de "reconstrução" e do uso da violência e do terror contra os afro-americanos, respectivamente ver FONER, Eric. Reconstruction: America's unfinished revolution, 1863-1877. New York: Harper \& Row, 1988 e FRANKLIN, John H. Raça e história: ensaios selecionados (1938-1988). Rio de Janeiro: Rocco, 1999.

14 "Jim Crow era um nome comum de escravo, e foi utilizado para intitular uma canção de Thomas Rice (1808-60), artista do século XIX. Essa canção ridicularizava os negros, retratando-os como idiotas engraçados, congenitamente preguiçosos, mas com uma aura de felicidade infantil. O nome foi aplicado à legislação que contribuiu para a prática da segregação entre brancos e afro-americanos". CASHMORE, Ellis. Dicionário de relações étnicas e raciais. São Paulo: Summus, 2000, p. 284.

${ }^{15}$ Para questões mais aprofundadas sobre o regime Jim Crow, ver LITWACK, Leon. Trouble in mind: black southerners in the age of Jim Crow. New York: Knopf, 1998 e WOODWARD, C. Vann. The strange career of Jim Crow. New York: Oxford University Press, 1974. ${ }^{16}$ ROSE, Arnold. Negro: o dilema americano. São Paulo: Ibrasa, 1968, p. 261.
} 
vam uma tabuleta informando ao público de tal procedimento. A dança entre negros e brancos era proibida, fosse negro o homem ou a mulher. $\mathrm{O}$ tabu contra o uso das mesmas praias ou piscinas era, também, rigoroso. Todavia, o principal símbolo da desigualdade social entre os dois grupos era, tradicionalmente, o tabu contra as refeições em conjunto. Nas conferências inter-raciais, nas quais costumavam haver refeições, os participantes negros eram às vezes servidos em salas separadas ou, quando na mesma sala, em mesas separadas. Nos refeitórios das fábricas, os negros comiam em salas separadas ou tinham que esperar que os brancos terminassem. A barreira ao casamento de pessoas dos dois grupos raciais ocupava um lugar de destaque no regime segregacionista. Tal tipo de casamento era proibido por lei em vários Estados.

No Sul dos EUA, as salas de espera, banheiros e bebedouros públicos eram separados. Nos logradouros públicos a "linha de cor" se repetia, assim como nos bairros. O intuito explícito era evitar os contatos entre brancos e negros. Se a população de origem africana vivesse apartada da população de origem européia, ambas não podiam criar laços de sociabilidade ou desenvolver atividades com base em interesses comuns. Muitos proprietários brancos jamais vendiam ou alugavam casas para negros; e quando alguma família negra conseguia estabelecer-se numa casa nos distritos dos brancos, passava logo a sentir, social e fisicamente, a aversão destes últimos. A segregação de moradias refletia nas escolas, bibliotecas, igrejas, nos hospitais e em outras instituições uni-raciais.

Muitos hospitais do Sul recebiam pacientes brancos e negros, mas estes ficavam isolados; as seções destinadas aos negros eram, na maior parte das vezes, inadequadas e inferiores, e não se permitia que médicos negros tratassem dos pacientes brancos. Nas fábricas, a "linha de cor" era comum em todo o Sul, conforme a indústria, o serviço ou o departamento. Os patrões preocupavam-se de construir instalações especiais, com banheiros, lavatórios e refeitórios separados. Os contatos de cordialidade entre negros e brancos nos Estados Unidos praticamente não existiam no espaço privado e, casualmente, aconteciam no espaço público (nas ruas, nos edifícios e meios de transporte públicos). $\mathrm{O}$ que prevalecia era o clima de tensão e animosidade. Baseados na idéia da supremacia racial, os brancos hostilizavam os negros.

Todas as formas de violência - como ameaças, pancadas, surras, roubos, destruição de propriedade - eram utilizadas contra os afro-americanos, principalmente nos estados do Sul. Entretanto, a forma de violência mais ostensiva era o linchamento. Segundo dados do Instituto Tuskegee, 4.715 pessoas foram 
linchadas de 1882 a 1946, sendo cerca de três quartas partes delas negras. ${ }^{17}$ Durante e logo depois da Primeira Guerra Mundial (1914-1919), houve um aumento no número de linchamentos. Com o passar dos anos tal modalidade de violência tornou-se, cada vez mais, fenômeno de ordem racial, muitas vezes precedido de tortura, mutilação e outros excessos permeados de sadismo. ${ }^{18}$

\section{Brasil: o sistema da democracia racial}

Em 1888, a lei Áurea aboliu a escravidão, o principal dispositivo institucional de opressão dos negros no Brasil. Em 1889, foi proclamada a República, que universalizou o direito à cidadania. Em tese, cidadãos de ascendência africana passaram a desfrutar de igualdade de direitos e oportunidades em relação aos de ascendência européia em todas as áreas da vida pública (educação, política, empregos, moradia). Foi nesse contexto que o Brasil - o último país do mundo ocidental a abolir a escravidão - tornou-se o primeiro a se proclamar uma democracia racial.

De acordo com George Reid Andrews, o conceito de democracia racial propugna que o Brasil é uma terra livre de qualquer barreira legal ou institucional para a igualdade racial e, em grande medida, também desprovida de qualquer manifestação de preconceito e discriminação raciais. Por isso, aqui, os afro-brasileiros desfrutariam de "oportunidades para se aprimorar e da liberdade para competir com seus concidadãos na luta por bens públicos e privados, em um grau desconhecido em qualquer outra sociedade multirracial do mundo". ${ }^{19}$

Havia, entretanto, uma contradição entre a imagem - de democracia racial - e a prática, de discriminação racial. Vários pesquisadores já apontaram a partir de lugares distintos - alguns muito próximos da realidade observada e, outros, nem tanto - que o negro levava desvantagem em relação ao branco na sociedade brasileira.

\footnotetext{
${ }^{17}$ Ibidem, p. 238.

${ }^{18}$ O regime Jim Crow nos Estados Unidos vigorou entre 1875 e 1954, quando as escolas segregacionistas foram declaradas inconstitucionais, um princípio estendido posteriormente aos ônibus, restaurantes, parques, etc. Na verdade, as leis Jim Crow foram sendo gradualmente derrubadas e sua dissolução total só ocorreu com o Ato dos Direitos Civis de 1964. ${ }^{19}$ ANDREWS, George Reid. Negros e brancos em São Paulo (1888-1988). Bauru: Edusc, 1998, p. 203.
} 
No que se refere a São Paulo, George Andrews investigou a política racial de uma empresa (a São Paulo Light), verificando que os negros enfrentavam mais dificuldades no momento da contratação e eram os primeiros a serem demitidos nas primeiras décadas do século $\mathrm{XX} .{ }^{20}$ Samuel Lowrie constatou que, entre 1920 e 1928, a taxa de mortalidade era superior na "população de cor" do que na branca, por sua vez, a taxa de natalidade era maior nesta população do que naquela. ${ }^{21}$ Boris Fausto certificou-se de que a Justiça de São Paulo condenava em maior proporção os acusados negros entre 1880 e 1924, ao passo que a absolvição ocorria em maior escala para os acusados brancos. ${ }^{22}$

Nesse período, havia instituições religiosas que rejeitavam o ingresso de negros. Um desses casos era a ordem dos franciscanos. ${ }^{23}$ Em algumas escolas não se aceitava a matrícula de alunos “de cor". Em outras, tais alunos recebiam um tratamento diferenciado em relação aos brancos. Determinados restaurantes, bares e barbearias não atendiam negros. Estes também não eram admitidos como sócios de clubes e eram impedidos de ingressar em hotéis e casas de lazer, como cinemas, teatros e salões de baile. ${ }^{24}$

No Rio Grande do Sul, o quadro não era diferente. Ao pesquisar a situação dos "homens de cor" nesse Estado no período posterior à Abolição, Fernando Henrique Cardoso detectou que eles eram preteridos nos "diversos planos da vida social: no trabalho, na religião, na recreação, nas escolas, e assim por diante". Nas palavras de Cardoso, as práticas discriminatórias tinham a função "evidente de impedir que o negro pudesse partilhar de forma comum com os brancos os benefícios da ordem formalmente democrática, como, por exemplo, freqüentar as mesmas escolas, ou dançar nos mesmos salões". ${ }^{25}$

${ }^{20}$ Ibidem.

${ }^{21}$ LOWRIE, Samuel. "O elemento negro na população de São Paulo". Revista do Arquivo Municipal, São Paulo, vol. 4, n. 48, 1938, pp. 22-23.

${ }^{22}$ FAUSTO, Boris. Crime e cotidiano: a criminalidade em São Paulo (1880-1924). São Paulo: Brasiliense, 1984, p. 236.

${ }^{23}$ ANDREWS, G. Negros e brancos em São Paulo, op. cit., p. 318.

${ }^{24}$ DOMINGUES, Petrônio. Uma história não contada: negro, racismo e branqueamento em São Paulo no pós-abolição. São Paulo: Ed. Senac, 2004.

${ }^{25}$ CARDOSO, Fernando Henrique. Capitalismo e escravidão no Brasil meridional. 4. ed. Rio de Janeiro: Paz e Terra, 1997, p. 252. 
$\mathrm{Na}$ Bahia, as desigualdades de tratamento se repetiam. Thales de Azevedo documentou como, em Salvador, as "pessoas de cor" eram impedidas de ingressar em clubes sociais e recreativos, em irmandades religiosas; enfrentavam dificuldades de seguir a carreira militar, sobretudo na Marinha e na Aeronáutica; não tinham oportunidades nas produções teatrais, pois, mesmo para os papéis de "pretos", preferiam-se brancos pintados. Azevedo assinala que era "extremamente raro um preto" em qualquer das escolas secundárias particulares nas primeiras décadas do século XX. Inclusive, "uma dessas escolas recusou matrícula a um estudante muito escuro", em 1915. ${ }^{26}$

Para o Rio de Janeiro, Costa Pinto revelou como o cenário de disparidades raciais persistia na década de 1940, fosse no mercado de trabalho, na educação, na habitação, etc. O negro ainda era alvo de estereótipos negativos. Segundo Pinto, tais estereótipos "funcionavam como barreiras, quer de ordem objetiva, quer de ordem subjetiva, que impediam ou dificultavam a ascensão social do negro". ${ }^{27}$

Os dados dessas pesquisas constituem evidências insofismáveis de que os negros continuaram a ocupar uma posição de subalternidade na sociedade brasileira no pós-Abolição; logo, é permitido sugerir que o discurso da democracia racial não passava de um "mito". Mas como interpretá-lo? No mundo acadêmico, duas são as principais matrizes interpretativas do mito da democracia racial. Uma delas concebe o mito a partir do conceito de ideologias, que seriam imagens invertidas do mundo real e artifícios que os grupos dominantes forjam para escamotear as formas de opressão. Partindo dessa premissa, pode-se argumentar que o preconceito e a discriminação sempre existiram na sociedade brasileira, e que o mito da democracia racial foi uma distorção - deliberada ou involuntária - do real padrão das relações raciais no Brasil. ${ }^{28}$ No entanto, essa interpretação tem alguns problemas. Um deles é seu caráter instrumental e conspirativo. Fica-se com a impressão que as classes superiores brancas sempre tiveram um comportamento maquiavélico e utilizaram o discurso da democracia racial como recurso ideológico para ocultar a opressiva realidade de racismo

\footnotetext{
${ }^{26}$ AZEVEDO, Thales de Azevedo. As elites de cor numa cidade brasileira. 2. ed. Salvador: EDUFBA-EGBA, 1996, pp. 100, 101, 104, 111, 118, 141.

${ }^{27}$ PINTO, L. A. Costa. O negro no Rio de Janeiro. 2. ed. Rio de Janeiro: Ed. UFRJ, 1998, p. 187.

${ }^{28}$ Ver, entre outros, FERNANDES, Florestan. A integração do negro na sociedade de classes. Vol. 1, 3. ed. São Paulo: Ática, 1978, especialmente o tópico "O mito da democracia racial", pp. 249-269.
} 
que a população negra ficou submetida. Um outro problema é apontado por Emília Viotti da Costa:

Não há dúvida de que o mito mascararia a real natureza das relações raciais no Brasil e esconderia o preconceito e a discriminação. Ele tornaria o desenvolvimento da consciência negra mais difícil e o confronto racial menos provável. E também escusaria as classes superiores brancas de tomar providências para evitar a marginalização da maioria negra. Mas isso não significa dizer que ele tenha sido criado expressamente pela elite branca para cumprir essas funções. Não podemos inferir intenções e finalidades de efeitos e funções. Em outras palavras, devemos distinguir as funções do mito de seus usos (manipulação expressa). Qualquer tentativa de negar o preconceito racial somente pode suscitar a suspeita de ser um ato de má-fé depois que o mito tiver sido identificado e desvendado. ${ }^{29}$

Para a segunda matriz interpretativa, mito não é simplesmente falsa ideologia, mas um discurso sobre a origem das coisas, um discurso sobre o cotidiano das pessoas, que não precisa ser real; pelo contrário, é efetivo na exata medida em que orienta a ação das pessoas, conferindo sentido às relações sociais no dia-a-dia. Nessa perspectiva, democracia racial deve ser apreendida como um ideal a ser alcançado e que é muito importante para a idéia de nação brasileira. ${ }^{30}$ Antônio Sérgio Guimarães refuta esta matriz interpretativa. Se de um lado esse argumento ensinaria a pensar as relações sociais no plano cotidiano, estabelecendo fim à politização excessiva do tema; por outro, tem um defeito: "Ele acaba se apegando muito à idéia de estrutura, de longa duração, torna-se quase que um discurso a-histórico, como se estivéssemos tratando com uma matriz que não teve início e não terá fim. Se os que usam tal argumento são pouco críticos a respeito da historicidade dessa matriz, então eu os fustigo, perguntando: como nasceu a democracia racial?". ${ }^{31}$

\footnotetext{
${ }^{29}$ COSTA, Emília Viotti da. "O mito da democracia racial”. Da Monarquia à República: momentos decisivos. 7. ed. São Paulo: Fundação Editora da Unesp, 1999, p. 375.

${ }^{30}$ Ver, entre outros, FRY, Peter. A persistência da raça: ensaios antropológicos sobre o Brasil e a África austral. Rio de Janeiro: Civilização Brasileira, 2005.

${ }^{31}$ GUIMARÃES, Antônio Sérgio Alfredo. "Como trabalhar com 'raça' em sociologia". Educação e Pesquisa. São Paulo, vol. 29, n. 1, 2003, p. 104.
} 
Apesar da contradição com a realidade, a idéia de que o Brasil era um país livre de barreiras que impediam o progresso social de negros a posições de riqueza e prestígio, remontava-se à época colonial, espraiando-se no período do Império e amplamente aceito nas primeiras décadas da República. ${ }^{32}$ A elite branca brasileira tinha sido educada desde o período colonial a ver os negros como inferiores. Tinha também aprendido a abrir exceções para alguns indivíduos negros ou mulatos. ${ }^{33}$ Assim, embora afirmando a superioridade dos brancos sobre os negros nas primeiras décadas do século XX, a elite aceitava "pessoas de cor" em seu meio. E tinha o desejo de eliminar o "problema" do negro no futuro, por intermédio da mestiçagem. Fomentando a miscigenação, a população tornar-se-ia cada vez mais branca. Para uma ideologia segregacionista característica dos Estados Unidos, onde qualquer descendente de uma união entre uma pessoa negra e branca era considerada negra, a elite brasileira forjou uma ideologia baseada na assimilação, em que mulatos eram classificados no meio do caminho entre negros e brancos. ${ }^{34}$

\footnotetext{
${ }^{32}$ Geralmente, a origem do termo "democracia racial" é atribuído a Gilberto Freyre, a partir da obra Casa Grande \& Senzala, de 1933. O intelectual pernambucano teria pensado a democracia racial, basicamente, como um modo diferente de o português colonizar que significou "miscigenar-se, igualar-se, integrar os culturalmente inferiores, absorver sua cultura, darlhes chances reais de mobilidade social no mundo branco". Freyre ainda pensaria que, "no Brasil, apesar de uma estrutura política muito aristocrática, desenvolveu-se, no plano das relações raciais, relações democráticas. São essas idéias que foram traduzidas como 'democracia racial' e ganharam por um bom tempo [...] a conotação de um ideal político de convivência igualitária entre brancos e negros". Ver GUIMARÃES, A. Como trabalhar com "raça”, op. cit., p.102. Porém, é mister fazer uma reparação. Gilberto Freyre não foi o autor do termo "democracia racial"; o antropólogo francês Roger Bastide foi provavelmente quem primeiro o empregou. Conforme ilação de Antônio Sérgio Guimarães, isso ocorreu num artigo que Bastide publicou no jornal Diário de São Paulo, em 31 de março de 1944. Gilberto Freyre só teria utilizado pela primeira vez um termo sinônimo de democracia racial em suas conferências na Universidade do Estado de Indiana (Estados Unidos), entre setembro e dezembro de 1944. Ver GUIMARÃES, Antônio Sérgio Alfredo. "Democracia racial: o ideal, o pacto e o mito”. Classes, raças e democracia. São Paulo: Editora 34, 2002, p. 138.

${ }^{33}$ Os arautos da democracia racial aproveitaram os exemplos raros de negros e mulatos que se projetaram na vida e os adotaram como regra do sistema racial, qual seja, eles transformaram os casos isolados em generalizações. Ver DOMINGUES, Petrônio. "O mito da democracia racial e a mestiçagem no Brasil (1889-1930)". Diálogos Latinoamericanos. Dinamarca, n. 14, 2005, p. 120. ${ }^{34}$ COSTA, E. O mito da democracia racial, op. cit., p. 371. Para Carl Degler, a figura do "mulato" foi a principal originalidade do sistema racial brasileiro. Categoria intermediária entre pessoas negras e brancas, o mulato seria a "válvula de escape" que teria abrandado o preconceito e a discriminação e aumentado "ainda mais as oportunidades para pessoas de cor no Brasil do que nos Estados Unidos". DEGLER, Carl N. Nem preto nem branco: escravidão e relações raciais no Brasil e nos EUA. Rio de Janeiro: Labor, 1976, p. 282.
} 


\section{0 paraíso versus inferno racial}

Quando esteve no Brasil, Robert Abbott fez uma série de conferências, comparando o cenário racial daqui com o de seu país de origem. Em São Paulo, o jornalista afro-americano foi recebido por alguns representantes das organizações negras e teria ficado sensibilizado com a campanha que eles realizavam em prol da construção do monumento em homenagem à "Mãe Negra". Ao voltar para os Estados Unidos, Abbott procurou manter-se informado da campanha. Para tanto, passou a fazer permuta de seu jornal, o Chicago Defender, com um dos jornais da imprensa negra paulista, O Clarim da Alvorada. ${ }^{35}$

Cabe agora retomar a questão central do presente artigo: afinal, por que o jornalista e empresário afro-americano Robert Abbott, mesmo tendo seus direitos civis violados no Brasil ${ }^{36}$ e fazendo contato com ativistas negros, avaliava que esse país teria ficado salvo do problema racial? A resposta mais plausível está relacionada ao fato de ele só conseguir compreender preconceito racial a partir da experiência norte-americana de preconceito. Na década 1920, as duas principais explicações

${ }^{35}$ LEITE, José Correia. E disse o velho militante José Correia Leite: depoimentos e artigos. Organizado por Cuti. São Paulo: Secretaria Municipal da Cultura, 1992, pp. 78-79. Também ver GOMES, Flávio. Negros e política (1888-1937). Rio de Janeiro: Jorge Zahar, 2005, p. 43. A expressão imprensa negra é uma referência aos jornais produzidos por negros e voltados para tratar de suas questões. Alguns desses jornais registraram a estada de Robert Abbott no Brasil e polemizaram com suas idéias. Ver Getulino (Campinas, 21 de outubro de 1923) e $O$ Kosmos (São Paulo, 18 de abril de 1923).

${ }^{36}$ Não se pode olvidar que o consulado brasileiro impôs dificuldades para conceder visto de entrada a Robert Abbott e que alguns hotéis não o aceitaram como hóspede pelo fato de ele ser negro. A postura do corpo diplomático brasileiro diante de Abbott não foi acidental. Em 1921, o Brazilian-American Colonization Syndicate (BACS) manifestou interesse em adquirir concessões de terras no interior de Mato Grosso, a fim de colonizá-las com afro-americanos. Quando o presidente de Mato Grosso (um bispo católico) soube que os colonos eram pretos, cancelou as concessões. Desde a abolição da escravidão, escreve Lesser, "o principal objetivo da política imigratória brasileira era o de 'branquear' a população do País, encorajando, por um lado, a entrada de agricultores europeus, e banindo, por outro, a entrada de africanos e asiáticos". Como os imigrantes afro-americanos eram "considerados racialmente indesejados", o Itamarati adotou, ao longo da década de 1920, a política de dificultar ou vetar a entrada deles no Brasil, embora tenham sido feitas exceções, de modo a não provocar incidentes diplomáticos de proporções mais amplas. LESSER, Jeffrey. "Legislação imigratória e dissimulação racista no Brasil (1920-1934)"'. Arché, Rio de Janeiro, vol. 3, n. 8, 1994, p. 81. Ver também RAMOS, Jair de Souza. "Dos males que vêm com o sangue: as representações raciais e a categoria do imigrante indesejável nas concepções sobre imigração na década de 20". MAIO, Marcos Chor; SANTOS, Ventura (orgs.). Raça, ciência e sociedade. Rio de Janeiro: Fiocruz, 1998. 
de lá para o fenômeno do racismo não se aplicavam ao caso brasileiro. O pressuposto básico da primeira explicação é que o preconceito existe como uma reação de um grupo racial (o branco) que se sente ameaçado por outro (o negro) na competição por recursos em uma ordem igualitária (democrática). Os especialistas julgavam que o preconceito, assim definido, não existia no Brasil. Até haveria casos individuais de preconceito, mas eram casos isolados e não um fenômeno social; ou seja, os brancos, como grupo, jamais se sentiram ameaçados de perder para os negros sua posição de poder, prestígio e riqueza na sociedade brasileira, por isso nunca desenvolveram o preconceito racial. ${ }^{37}$

A segunda explicação sustentava que racismo era sinônimo de segregacionismo institucionalizado, isto é, um sistema separatista imposto pelo grupo de brancos ao grupo de negros, por intermédio de uma série de leis proibitivas ou restritivas de direitos. Combinado ao segregacionismo, racismo se traduziria num sistema baseado em manifestações explícitas de ódio racial. ${ }^{38}$ Nos Estados Unidos, não era incomum os brancos recorrerem à violência contra a vida, a segurança pessoal e a liberdade dos negros. Conquanto essa prática tenha origem na escravidão, continuava a florescer nas primeiras décadas do século XX. Qualquer pessoa branca podia agredir uma negra moral ou fisicamente e, em última instância, tirar-lhe a vida sem ter maiores temores quanto à represália da lei. Como, no Brasil, o negro não era alvo de um regime de segregacionismo institucionalizado e de manifestações virulentas de "preconceito de cor", acreditava-se que o país tivesse ficado livre do problema racial. Daí a imagem tão positiva que Abbott produziu da experiência negra no Brasil. Mas na medida em que o jornalista afro-americano ficou eivado pelos valores culturais de seu país de origem, não conseguiu perceber que a principal especificidade do racismo à brasileira era ser informal, plástico, dissimulado, enfim, não declarado. ${ }^{39}$

\footnotetext{
${ }^{37}$ GUIMARÃES, A. Como trabalhar com "raça”, op. cit., p.102.

${ }^{38}$ JONES, James M. Racismo e preconceito. Trad. Dante Moreira Leite. São Paulo: Ed. Blücher, 1973.

${ }^{39}$ PEREIRA, João Baptista Borges. "Racismo à brasileira”. MUNANGA, Kabengele (org.). Estratégias e políticas de combate à discriminação racial. São Paulo: Edusp, 1996, pp. 7578. Mais recentemente, o racismo à brasileira foi epitetado de cordial. Ver TURRA, Cleusa e VENTURI, Gustavo (eds.). Racismo cordial: a mais completa análise sobre o preconceito de cor no Brasil. São Paulo: Ática, 1995.
} 
A partir de que momento o sistema racial norte-americano passou a servir de parâmetro às avaliações brasileiras? Consoante Célia M. Marinho de Azevedo, a crença de que as relações entre brancos e negros nos dois países se diferenciavam radicalmente tem suas origens no movimento abolicionista. Em diversos "momentos e lugares, com o intuito de alcançar objetivos específicos de luta contra a escravidão, os abolicionistas lançaram as bases comparativas para que Estados Unidos e Brasil passassem a ser imaginados através do contraste entre inferno e paraíso". ${ }^{40}$ Teria sido em meados do século XIX que o Brasil tornou-se conhecido como "o próprio paraíso para os negros". ${ }^{41}$

Em 1871, Perdigão Malheiro, deputado por Minas Gerais e reconhecido jurista, discursou no plenário da Câmara dos Deputados, condenando o que considerava injustificadas e caluniosas críticas à harmonia racial brasileira: "Desde que para o Brasil vieram negros da Costa d'África, nunca houve esse desprezo pela raça africana, que, aliás, se notava em outros países, principalmente nos Estados Unidos”. Quando respondia se existia ou não preconceito de cor no Brasil, Malheiro era incisivo: "Senhores, eu conheço muitos indivíduos de pele escura que valem mais do que muitos de pele clara. Esta é a verdade. Não vemos nas escolas, nas academias, nas igrejas, ao nosso lado, homens distintos, bons estudantes, de pele de cor? Não vemos no parlamento, no governo, no Conselho de Estado, em missões diplomáticas, no exército, nas repartições públicas, gente de pele mais ou menos escura, de raça mestiça mesmo com a africana?". ${ }^{42}$

O abolicionista Joaquim Nabuco respaldava a assertiva de que o Brasil soubera evitar o preconceito racial. Ao escrever o libelo $O$ abolicionismo, em 1883, ponderava: "A escravidão, por felicidade nossa, não azedou nunca a alma do escravo contra o senhor - falando coletivamente - nem criou entre as duas raças o ódio recíproco que existe naturalmente entre opressores e oprimidos". Aqui, "o homem de cor achou todas as avenidas abertas diante de si". Além disso, a experiência histórica demonstrou que: "a cor, no Brasil, não é, como

\footnotetext{
${ }^{40}$ AZEVEDO, Célia Maria Marinho de. Abolicionismo: Estados Unidos e Brasil, uma história comparada (século XIX). São Paulo: Annablume, 2003, p.154.

${ }^{41}$ Ibidem, p. 157.

${ }^{42}$ Anais da Câmara dos Deputados, Sessão de 1871 (Rio de Janeiro, 1871), pp. 295-96 apud SKIDMORE, Thomas. Preto no branco: raça e nacionalidade no pensamento brasileiro. 2. ed. Rio de Janeiro: Paz e Terra, 1989, p. 39.
} 
nos Estados Unidos, um preconceito social contra cuja obstinação pouco pode o caráter, o talento, e o mérito de quem incorre nele". ${ }^{43} \mathrm{O}$ caráter harmonioso das relações entre os descendentes de europeus e os descendentes de africanos no Brasil era legitimado pela imagem que foi disseminada do cativeiro. À luz do sistema escravista norte-americano, qualificava-se a escravidão brasileira como mais amena e humana e os brasileiros brancos bastante tolerantes em relação à população livre de cor.

Outrossim, políticos e intelectuais abolicionistas estrangeiros partilhavam da crença geral de que o Brasil não abrigava preconceito racial. Um deles era o francês M. Quentin. Em uma preleção sobre o maior país da América do Sul, realizada em Paris, em 1867, ele avalizava essa crença:

O que facilitará singularmente a transição [para o trabalho livre] no Brasil é que lá não existe nenhum preconceito de raça. Nos Estados Unidos e em Cuba, todos os homens de cor, mesmo um liberto, são olhados de cima como inferiores pelos homens da raça branca. Não há nada disso no Brasil: lá todos os homens livres são iguais; e esta igualdade não é só da lei, mas é também da prática cotidiana. O liberto ingressa totalmente na vida social, civil e política. Observei os procedimentos em estabelecimentos de ensino (fui professor no Rio de Janeiro durante seis anos) em que alunos negros, mulatos e brancos seguiam o mesmo curso, compareciam às mesmas cerimônias, e nunca nenhum sarcasmo ou gracejo por partes dos brancos contra os seus colegas de cor. No teatro, na primeira fileira dos camarotes, a qual é chamada de fileira nobre, todas as raças estão representadas; nas posições públicas, mesmo nas mais altas, no Senado, na Câmara dos Deputados, no Conselho de Estado, os homens de cor proporcionam um contingente muito importante: é

\footnotetext{
${ }^{43}$ NABUCO, Joaquim. O abolicionismo. São Paulo: Ed. Nacional, 1938 [1883], p. 22-23. Não só Joaquim Nabuco, mas em outros líderes abolicionistas "encontramos a mesma ênfase em afirmar a ausência de preconceitos raciais. O abolicionista Rui Barbosa, por exemplo, acreditava que, ao contrário dos Estados Unidos, onde os negros sofriam perseguições violentas, o Brasil contava com proprietários de "índole benigna' e 'hábitos de humanidade"'. AZEVEDO, Célia Maria Marinho de. "Abolicionismo e memória das relações raciais". Estudos Afro-Asiáticos, Rio de Janeiro, n. 26, 1994, p. 10.
} 
mesmo raro que hão haja um homem de cor no ministério. A igualdade, portanto, não é apenas um direito: é um fato. ${ }^{44}$

Os abolicionistas norte-americanos - como Frederick Douglass - nunca deixaram de ressaltar o contraste entre o Brasil católico e monárquico, porém livre do racismo, e os Estados Unidos protestante e republicano, mas racista. Marinho de Azevedo nota que era corrente acreditar e, ao mesmo tempo, difundir a idéia que nos Estados Unidos as mais injustas barreiras de cor eram erigidas contra os ex-escravos e seus descendentes, "enquanto no Brasil os emancipados e seus filhos encontravam todas as 'avenidas' da sociedade abertas para eles". ${ }^{45}$

No que diz respeito ao período pós-escravista, norte-americanos brancos e negros reiteravam a opinião de Robert Abbott: o Brasil era um país sem preconceitos ou discriminações raciais, onde o valor e o mérito individual independiam da pertença racial ou da cor. Depois de visitar o Brasil em 1914, Theodore Roosevelt afirmou: "se me pedissem para dizer um ponto no qual existe uma diferença completa entre nós e os brasileiros, eu diria que é na atitude para com o homem negro... [No Brasil] qualquer negro ou mulato que se mostre capacitado conquista inquestionavelmente o lugar a que suas capacidades the dão o direito". ${ }^{46}$ David Hellwig apresenta uma série de artigos em que ativistas, escritores e intelectuais afro-americanos reforçavam a imagem do paraíso racial brasileiro. ${ }^{47}$ Líderes como Booker T. Washington e W. E. B. DuBois escreveram positivamente sobre a experiência negra no Brasil, enquanto o nacionalista negro Henry McNeal Turner e o jornalista Cyril Biggs chegaram a ponto de preconizar a emigração para o Brasil como refúgio da opressão racial nos Estados Unidos. ${ }^{48}$

\footnotetext{
${ }^{44}$ Apud AZEVEDO, C. Abolicionismo, op. cit., p. 158.

${ }^{45}$ AZEVEDO, C. Abolicionismo, op. cit., p. 164.

${ }^{46}$ ROOSEVELT, Theodore. "Brazil and the negro". Outlook, 21 fev. 1914, p. 410-411 apud ANDREWS, George Reid. "Democracia racial brasileira 1900-1990: um contraponto americano". Estudos Avançados. São Paulo, n. 30, 1997, p. 106.

${ }^{47}$ HELLWIG, David. "A new frontier in a racial paradise: Robert S. Abbott's Brazilian dream". Luso-Brazilian Review, vol. 25, n. 1, 1988.

${ }^{48}$ HANCHARD, Michael George. Orfeu e o poder: movimento negro no Rio de Janeiro e São Paulo (1945-1988). Rio de Janeiro: EdUERJ, 2001, p. 70. Durante a década de 1910 e 1920, jornais da imprensa afro-americana (Baltimore Afro-American, Atlanta Independent, Negro World e, o mais importante deles, The Crisis, de W. E. B. DuBois) também recomendavam aos seus leitores que pensassem em emigrar para o Brasil. Ver ANDREWS, G. Democracia racial brasileira, op. cit., p. 106.
} 
Foi durante o período pós-escravista que o mito da democracia racial se consolidou como dado integrante da identidade nacional. Nesse período, continuou habitual a elite política e intelectual brasileira negar a prática de discriminação racial, que geralmente identificava com a estrutura legal de segregação vigente nos Estados Unidos. ${ }^{49} \mathrm{Na}$ concepção de Jeff Lesser, a postura ideológica da elite brasileira vislumbrava continuar atraindo a imigração branca e, ao mesmo tempo, manter as "boas relações” do país com "outras repúblicas americanas, em especial com os Estados Unidos". ${ }^{50}$ Propalar a imagem de relações harmoniosas entre pessoas de cores distintas seria um componente a colocar o país em posição de vantagem no concerto das nações civilizadas. Assim, a elite pensava não apenas no Brasil, mas decerto também estava atenta às repercussões de seus discursos e atos em uma arena transnacional, mormente em território norte-americano.

O fato é que o discurso da democracia racial tornou-se lugar comum, de modo que até um setor da imprensa negra brasileira endossava tal discurso na década de 1920. O jornal Progresso, por exemplo, registrava em clima ufanista: "O Brasil pode, pois, ter a certeza de que se avantajou em muitos anos aos países cultos, quando extinguia o preconceito de cor, inadmissível, hoje em dia". ${ }^{51} \mathrm{O}$ jornal $O$ Clarim da Alvorada pintava um quadro ainda mais idílico: "Enquanto o negro norte-americano desbotoa o peito e se atira contra o branco numa luta exterminante, bárbara e sanguinária, arrastado pelo ódio mortal; [...] o negro brasileiro estende a mão da fraternidade aos seus irmãos brancos". Isto porque "no Brasil não há preconceitos". ${ }^{52}$ Percebe-se que, mais uma vez, o sistema racial brasileiro era representado como distinto e superior ao norteamericano. E foi justamente essa representação que despertou a atenção de Abbott. Com efeito, vale salientar: mais do que a representação, ele ficou impressionado com as peculiaridades que permeavam as relações raciais no Brasil: a ausência de discriminação legal, a aparente ausência de conflito racial e, possivelmente, com a taxa de mestiçagem (tendo em vista a proporção de casais e filhos mistos na população brasileira) e a presença de alguns negros e mulatos

\footnotetext{
${ }^{49}$ SKIDMORE, Thomas. O Brasil visto de fora. Rio de Janeiro: Paz e Terra, 1994, p. 108.

${ }^{50}$ LESSER, J. Legislação imigratória e dissimulação racista, op. cit., p. 89.

${ }^{51}$ Progresso (São Paulo, 24 de fevereiro de 1929).

${ }^{52}$ O Clarim da Alvorada (São Paulo, 4 de março de 1928). A ausência de preconceito racial também era ventilada pelo artigo "Os homens pretos e a evolução social", do jornal Auriverde. (São Paulo, 29 de abril de 1928).
} 
incorporados às camadas das elites. Todas essas peculiaridades - estranhas à experiência das relações raciais em seu país de origem - serviram para cimentar sua convicção de que o Brasil ficara isento do "preconceito de cor". ${ }^{53}$

Antes de finalizar, porém, cumpre perscrutar uma questão. Os últimos anos da década de 1910, nos Estados Unidos, foram marcados pelo agravamento dos antagonismos raciais. Tiago de Melo Gomes observa que uma escalada de conflitos protagonizados por brancos e negros iniciou-se em East St. Louis, Illinois, em 1917, propagando-se por diversas regiões do país ${ }^{54}$ e chegando ao auge no violento confronto de Chicago, que durou cinco dias em julho de 1919. Diante das leis segregacionistas e dos sangrentos linchamentos que se alastravam desde o século anterior, esse "ensaio de guerra racial talvez tenha sido o elemento que faltava para que grupos de afro-americanos intensificassem a busca por outros países onde pudessem receber um tratamento mais digno". ${ }^{55}$ Portanto, não se deve perder de vista que a série de artigos que Abbott publicou no Chicago Defender, em 1923, também tinha um caráter propagandístico, podendo inclusive supor que seu autor tenha carregado na tinta propositadamente. Quando celebrava a imagem do Brasil como um "éden” para os negros, Abbott instilava esperança entre seus "irmãos de cor" nos Estados Unidos que, muito depois da Abolição, viviam submetidos a um regime de marginalização social, econômica e política.

Essa suposição é reforçada quando se sabe que, ao voltar à sua pátria, Robert Abbott promoveu de fato uma campanha encorajando os afro-americanos a se transferirem para o Brasil. ${ }^{56}$ Estes até que se mobilizaram, mas quase todos os

\footnotetext{
${ }^{53}$ É importante reiterar essa assertiva: diferentemente dos Estados Unidos, o Brasil não tinha barreira de cor institucionalizada ou mesmo engendrou o clima de ódio racial. Também diferentemente dos Estados Unidos, em vez de dois grupos (brancos e negros), havia no Brasil um terceiro grupo - o mulato.

${ }^{54}$ Talvez o ato mais horrendo tenha ocorrido no estado da Geórgia, em 1918. Mary Turner, uma mulher negra grávida, foi enforcada numa árvore, embebida com gasolina e queimada. Quando se balançava na corda, "um homem da multidão puxou uma faca e abriu seu ventre. Seu filho caiu. Deu dois gemidos fracos - e recebeu como resposta um pontapé de um valentão". JONES, J. Racismo e preconceito, op. cit., p. 15.

${ }^{55}$ GOMES, Tiago de Melo. "Problemas no paraíso: a democracia racial brasileira frente à imigração afro-americana (1921)”. Estudos Afro-Asiáticos, Rio de Janeiro, ano 25, n. 2, 2003, p. 309.
} 
pedidos de vistos de entrada deles foram recusados pelo consulado do país que se vangloriava da fama de "paraíso racial". Para Abbott, aquelas recusas pareciam arbitrárias e de cunho racista. Seus advogados protestaram, contudo foi em vão. Ele então procurou provocar um incidente diplomático, tornando pública sua história. Mais uma vez, seus esforços não lograram êxitos, pois muitos dos pedidos de vistos de afro-americanos continuaram a ser recusados regularmente pelo consulado brasileiro na década de 1920.

\footnotetext{
${ }^{56}$ Quando Robert Abbott visitou o Brasil, o movimento negro estadunidense - ao menos aqueles setores capitaneados por Marcus Garvey - proferia em escala crescente um discurso diaspórico, particularmente discutia o retorno à África. Garvey, por exemplo, elaborou um projeto apontando a Libéria (considerada a "nação central para a raça negra") como um dos pólos de emigração afro-americana. Nesse contexto, o Brasil provavelmente entraria como uma outra opção, embora não prioritária.
} 